\title{
SELECTION OF SUPERIOR CLONES OF Corymbia HYBRIDS BASED ON WOOD AND CHARCOAL PROPERTIES
}

\author{
Breno Assis Loureiro ${ }^{1, \diamond}$, Túlio Anselmo Sacramento Vieira ${ }^{1}$, Luciano Junqueira Costa ${ }^{2}$, \\ Alanna Barishinikov Silva ${ }^{1}$, Maíra Reis de Assis ${ }^{1}$, Paulo Fernando Trugilho ${ }^{1}$
}

\begin{abstract}
The use of fast-growing trees is a good economic strategy for charcoal production. Wood with adequate chemical and physical properties generally is positively correlated with charcoal quality. The objective of this research was to evaluate wood quality from fast-growing hybrids for charcoal production. Three Corymbia citriodora $x$ Corymbia torelliana and four Corymba torelliana x Corymba citriodora hybrid clones were evaluated. Parameters used to evaluate wood quality were wood basic density, elemental and structural chemical composition, energy efficiency and thermogravimetric analysis and the parameters evaluated for charcoal quality were apparent relative density, gravimetric yield, high heating value, proximate analysis and energy efficiency. All clones had wood basic density superior than $0,5 \mathrm{~g} \mathrm{~cm}^{-3}$ and ash inferior than $1 \%$, which are desirable for a good quality of charcoal. Lignin content did not differ among clones with an average less than the $28 \%$ recommended for energetic use. Although clones differed in wood parameters, as dry matter, high heating value, energy density, total extractives, holocellulose content, it did not reflect in charcoal quality differences. Wood from all clones had equal and satisfying high heating value of charcoal and energy efficiency quality for charcoal production and differed in apparent relative density and ash content.
\end{abstract}

Keywords: Bioenergy, carbonization, elemental compositions, heating values, thermal characterization.

\section{INTRODUCTION}

Brazil is one of the largest producers and consumers of charcoal in the world (FAO 2019) and has the potential to increase production. One strategy to increase production is to cultivate fast-growing trees associated with reduction of the cutting cycle which quickly reach an economically optimum size. Species cultivated for charcoal production have had their growth-cycle reduced from 7 years to 5 or 4 years due to successful breeding programs (Oliveira et al. 2010). Fast-growing trees need to be assessed for wood quality and charcoal production; hybrids breeding strategies have improved these parameters and produced superior clones.

Corymbia species stand out for charcoal production because of their desirable high wood volume and density (Lee 2007). In addition, some species are tolerant to diverse pests and diseases, as well as environmental stressors such as wind, cold, frost, and drought (Lee 2007). Interspecific hybrids of Corymbia have high biomass production and grow faster than open-pollinated seed batches (Lee et al. 2009). Creating hybrids from Corymbia citriodora and Corymbia torelliana genotypes increases the chance that the resulting plants will be more vigorous than either parent (Reis et al. 2014).

Selecting superior clones helps optimize charcoal production in order to meet industry requirements (Protásio et al. 2014, Protásio et al. 2015, Assis et al. 2015). The most important parameters for clone selection are wood basic density (WBD), dry matter (DM), high heat value (HHV), elemental chemical composition, lignin content (LIG), extractive content (EXT), holocellulose (HOLO) and energy density (ED) (Guo et al.

\footnotetext{
${ }^{1}$ Department of Forest Sciences, Universidade Federal de Lavras (UFLA), Lavras, Minas Gerais, Brazil.

${ }^{2}$ Department of Forest Engeneering, Universidade Federal de Viçosa (UFV), Viçosa, Minas Gerais, Brazil.

•Corresponding author: loureiro_breno@yahoo.com.br
}

Received: 03.02.2018 Accepted: 20.08.2019 
2010, Gonçalves et al. 2015, Protásio et al. 2019).

Wood basic density directly correlates with the gravimetric yield during the carbonization process and with the apparent relative density of the charcoal (Moutinho et al. 2016, Andrade et al. 2018). For carbonization, wood basic density greater than $500 \mathrm{~kg} \cdot \mathrm{m}^{-3}$ is desirable (Santos et al. 2011). Some factors that affect carbonization are lignin, extractive content, and holocellulose content (Silva and Ataíde 2019).

Lignin is positively correlated with charcoal yield (Pereira et al. 2013, Soares et al. 2014) and it is associated with the resistance to thermal degradation (Haykiri-Acma et al. 2010). Lignin is a complex polymer synthesized mainly from three monomers: p-hydroxyphenyl, guaiacyl, and syringyl, which differ in the number of methoxyl groups (Wang et al. 2017), and this important component of cell wall are significantly influenced by age of lignocellulosic material (Healey et al. 2016). A minimum lignin content of $28 \%$ is required for costeffective charcoal production (Pereira et al. 2013).

Wood extractives are molecules that are extracted from wood and consist of waxes, fatty acids, resin acids, and terpenes. Extractives with resistant chemical bonds release high amounts of energy when broken (Fengel and Wegener 1989). The remaining fibrous residue after the extractives, lignin, and ash-forming elements have been removed from the biomass is called holocellulose. Species with low percentages of holocellulose and high contents of lignin and extractives should be selected for charcoal as this increase resistance to thermal degradation (Fialho et al. 2019, Pereira et al. 2013).

Charcoal quality can be assessed by proximate analysis, gravimetric yields, and apparent relative density. Proximate analysis determines the composition of charcoal after it is burned as moisture, volatile matter, fixed carbon, and ash. Fixed carbon is the portion of charcoal that remains as residue after removing volatile matter, moisture, and ash. For blast furnace operation, fixed carbon content greater than $75 \%$ is preferred (Bruzual 2015). Ash is the inorganic residue that remains after combustion; for steel use charcoal should have a maximum of 1,5\% ash (Rousset et al. 2011). Ash may also affect burning and make gasification difficult due to interactions between the inorganic fraction and the combustible matter (Lin et al. 1994).

The purpose of this research was to evaluate seven fast-growing hybrid clones of Corymbia for charcoal production and to select the best clones for charcoal quality.

\section{MATERIAL AND METHODS}

\section{Plant material and growth conditions}

Three clones of $C$. citriodora $\mathrm{x} C$. torelliana $(\mathrm{Cc} \times \mathrm{Ct})$ and four clones of $C$. torelliana $\mathrm{x} C$. citriodora $(\mathrm{Ct} \times \mathrm{Cc})$ were used in this research (Table 1). The trees, 45 months old, came from a commercial plantation belonging to Aperam Bionergia, and were located at Itamarandiba, Minas Gerais, Brazil $\left(17,86^{\circ} \mathrm{S}\right.$ latitude and $42,86^{\circ} \mathrm{W}$ longitude). The climate is subtropical humid (Cwa), according to the Köppen classification (Peel et al. 2007), with an average annual temperature of $20,1^{\circ} \mathrm{C}$, average annual humidity of $78 \%$, and average annual rainfall of $1.076 \mathrm{~mm}$. The experiment was set up in a completely randomized design with seven clones and five biological replications per clone. Trees were spaced in $3 \times 3 \mathrm{~m}$.

Discs of approximately $2,5 \mathrm{~cm}$ thick were collected longitudinally in the position of $0 \%, 2 \%, 10 \%$, $30 \%, 50 \%, 70 \%$, and $100 \%$ of the commercial height of each tree (Downes et al. 1997, Trugilho 2009). The commercial height is the height at which the tree circumference is $9,4 \mathrm{~cm}$ measured from the $0 \%$ position which refers to the tree base. Wood volume per tree was calculated using the Smalian method. After wood volume analysis, the discs were fragmented into four wedges. Two wedges located on opposite sides of the discs were used for wood basic density analysis. The other two wedges were used for further analysis. The wood was evaluated for basic density, dry matter, high heat value, elemental chemical composition, extractive content, and energy density. The charcoal produced from each clone sample was evaluated for proximate composition, gravimetric yield, apparent relative density, and thermogravimetric analysis. 
Table 1: Characteristics of the seven hybrid clones of Corymbia.

\begin{tabular}{|l|l|c|c|c|}
\hline Clones & Crossing & $\begin{array}{c}\text { Mean } \\
\text { diameter* } \\
(\mathbf{c m})\end{array}$ & $\begin{array}{c}\text { Commercial } \\
\text { height } \mathbf{( m )}\end{array}$ & $\begin{array}{c}\text { Volume without } \\
\text { bark } \mathbf{( m}^{\mathbf{3}} \mathbf{)}\end{array}$ \\
\hline Cc x Ct-1 & C. citriodora $x$ C. torelliana & $10,48^{(1,18)}$ & $10,85^{(0,60)}$ & $0,03900^{(0,0090)}$ \\
\hline Cc x Ct-2 & C. citriodora $x$ C. torelliana & $12,15^{(1,88)}$ & $11,96^{(0,98)}$ & $0,0530^{(0,0144)}$ \\
\hline Cc x Ct-3 & C. citriodora $x$ C. torelliana & $14,83^{(2,12)}$ & $15,08^{(0,73)}$ & $0,0927^{(0,0223)}$ \\
\hline Ct x Cc-4 & C. torelliana $x$ C. citriodora & $12,71^{(1,00)}$ & $11,07^{(0,43)}$ & $0,0572^{(0,0066)}$ \\
\hline Ct x Cc-5 & C. torelliana $x$ C. citriodora & $11,19^{(1,06)}$ & $10,85^{(0,85)}$ & $0,0469^{(0,0099)}$ \\
\hline Ct x Cc-6 & C. torelliana $x$ C. citriodora & $11.80^{(1,95)}$ & $12,56^{(0,27)}$ & $0,0654^{(0,0108)}$ \\
\hline Ct x Cc-7 & C. torelliana $x$ C. citriodora & $12,69^{(1,22)}$ & $12,76^{(0,85)}$ & $0,0632^{(0,0133)}$ \\
\hline
\end{tabular}

* The mean diameter, from five trees per clone, refers to the diameter at breast height which is $1,30 \mathrm{~m}$ above ground level.

\section{Wood property evaluations}

Wood basic density (WBD) was determined using the standard ABNT NBR 11941 (2003). The dry matter content was obtained by Equation 1.

$$
D M=V w s x W B D
$$

Where, DM: dry matter; Vws: wood volume without bark; WBD: wood basic density.

The ultimate analysis (quantification of $\mathrm{C}, \mathrm{H}, \mathrm{N}, \mathrm{O}$ and $\mathrm{S}$ ) and high heating value of the wood (HHVw) were performed in wedges from all disc's positions sampled.

The ultimate analysis was determined from material that was oven-dried in a universal analyzer (Elementar ${ }^{\circledR}$ Vario Micro Cube). Two milligrams of material were passed through 200-mesh sieve and were retained in the 270-mesh sieve was used. The ratios $\mathrm{O} / \mathrm{C}$ and $\mathrm{H} / \mathrm{C}$ were calculated according to Elaieb et al. (2018) and used to create a van Krevelen diagram (van Krevelen 1993, Ronsse et al. 2015).

The HHVw was determined using an IKA C200 digital calorimeter, according to ASTM E711-87 standard (ASTM 2004) and the energy density (ED) was obtained according to Equation 2.

$$
E D=B D \times H H V w
$$

Where, ED: energy density $\left(\right.$ Gcal.m $\left.{ }^{-3}\right)$; WBD: wood basic density $\left(\mathrm{kg} . \mathrm{m}^{-3}\right)$; HHVw: high heating value of wood $\left(\mathrm{kcal}_{\mathrm{kg}} \mathrm{kg}^{-1}\right.$.

The total extractive content was determined with the standard TAPPI 204 om-88 (TAPPI 2001), replacing ethanol/benzene with ethanol/toluene. The insoluble lignin content was determined by the modified Klason method, according to the procedure recommended by Gomide and Demuner (1986). The soluble lignin content was obtained according to the procedure proposed by Goldschmid (1971). The total lignin content consists of both soluble and insoluble lignin. The percentage of ash in the wood was determined according to standard NBR 13999 (ABNT 2017). The holocellulose content was obtained by the sum of extractive, ash, and total lignin contents subtracted from 100. 


\section{Charcoal properties evaluation}

Carbonization was performed using an electric furnace connected to a condenser cooled by water and connected to a collection vial for condensable gases. The samples were previously oven dried at $105 \pm 3{ }^{\circ} \mathrm{C}$ and placed in a metal container with nominal dimensions of 30 by $12 \mathrm{~cm}$. The total carbonization time was 4 hours with a heating rate of $1,67^{\circ} \mathrm{C} \mathrm{min}$. The carbonization started at a temperature of $100{ }^{\circ} \mathrm{C}$, up to a maximum temperature of $450^{\circ} \mathrm{C}$, with a residence time of 30 minutes. After carbonization, the gravimetric yields (GYC), pyroligneous liquid (GYPL), and non-condensable gases (GYNCG) were all determined in relation to wood dry matter. Charcoal apparent relative density (ARD) was determined by immersion in water according to the hydrostatic method.

The high heating value of charcoal (HHVc) was obtained as described for HHVw. Proximate analysis was used to determine the contents of volatile materials (VM), ash (ASH), and fixed carbon (FC), according to the procedure established in standard ASTM D1762-84 (2007). The energy efficiency of the carbonization was calculated using Equation 3.

$$
E E=\frac{H H V c^{*} G Y C}{H H V w}
$$

Where, EE: energy efficiency (\%); HHVc: high heating value of charcoal (kcal.kg-1); GCY: gravimetric charcoal yield (\%); HHVw: high heating value of wood $\left(\mathrm{kcal}^{\mathrm{kg}} \mathrm{kg}^{-1}\right)$.

Thermogravimetric analysis (TG/DTG) was performed using a nitrogen flow rate of $50 \mathrm{~mL} \mathrm{~min}^{-1}$ using the automatic thermal analyzer DTG-60H (Shimadzu). Mean values were calculated by the equipment software TA60 Version 2.20. Samples of approximately $4 \mathrm{mg}$ were subject to a gradient temperature, ranging from ambient temperature $\left(25 \pm 5{ }^{\circ} \mathrm{C}\right)$ to $600{ }^{\circ} \mathrm{C}$, with a heating rate of $10{ }^{\circ} \mathrm{C} \mathrm{min}{ }^{-1}$.

\section{Statistical analysis}

Multiple mean comparisons were performed using Scott-Knott test at $\alpha=0,05$ for all wood and charcoal analyses. The analyses were performed using R Statistical software version 3.3.3 (R CORE TEAM 2016). Pearson's correlation (Pereira et al. 2013, Andrade et al. 2018) and linear regression analyses at $\alpha=0,05$ were conducted to test for correlation and relationships among parameters evaluated.

\section{RESULTS AND DISCUSSION}

\section{Wood evaluations}

Wood basic density (WBD) was evaluated in all seven clones. All clones had the desired amount of WBD carbonization which is greater than $500 \mathrm{~kg} . \mathrm{m}^{-3}$ (Santos et al. 2011). However, clone $\mathrm{Ct} \times \mathrm{Cc}-5$ had the highest WBD which could be more beneficial for charcoal production (Table 2). WBD is one of the most important selection parameters for quality charcoal production because it is associated with better mechanical resistance (Chrzazvez et al. 2014, Moutinho et al. 2016). A positive correlation was observed between WBD and charcoal density (Brito and Barrichelo 1980). Denser wood results in more energetic charcoal.

The DM has been shown to be positively correlated with WBD (Zanuncio et al. 2015). However, for the clones evaluated, the DM was similar for all but one clone: $\mathrm{Cc} \times \mathrm{Ct}-3$, which had the highest DM. The HHV is affected by chemical composition and wood moisture (Ashton and Cassidy 2007) and it reflects the amount of energy released when fuel is consumed. Highest HHV was observed in clones $\mathrm{Cc} \times \mathrm{Ct}-2, \mathrm{Cc} \times \mathrm{Ct}-3, \mathrm{Ct} \times$ $\mathrm{Cc}-4$, and $\mathrm{Ct} \times \mathrm{Cc}-6$ (Table 2). These clones were only 3 years and 9 months old and had HHV ranging from 4577 to 4670 kcal. $\mathrm{kg}^{-1}$. Seven-year-old trees from genus Corymbia had HHV ranging from 4570 to $4663 \mathrm{kcal}$. 
$\mathrm{kg}^{-1}$ (Zanuncio et al. 2014a, Zanuncio et al. 2014b). These results highlight the potential of these clones to be used for charcoal production, especially since they have high HHV at almost half age of others Corymbia trees. The ED was highest for clone $\mathrm{Ct} \times \mathrm{Cc}-5$ and lowest for clone $\mathrm{Cc} \times \mathrm{Ct}-2$, and $\mathrm{ED}$ was positively correlated with WBD with correlation coefficient of 0,99 ( $p$-value $<0,01 ; \mathrm{R}^{2}=0,98 ; \mathrm{y}=0,0044 \mathrm{x}+0,1076$; Figure 1$)$. The two most important parameters that reflect productivity and wood quality are WBD and HHV (Protásio et al. 2017) and may be used for selection of clones for charcoal production.

Table 2: Mean values of WBD, DM, HHV and ED of the seven clones.

\begin{tabular}{ccccc}
\hline Clones & $\begin{array}{c}\text { WBD } \\
\left(\mathrm{kg} \cdot \mathrm{m}^{-3}\right)\end{array}$ & $\begin{array}{c}\mathrm{DM} \\
(\mathrm{kg})\end{array}$ & $\begin{array}{c}\text { HHVw } \\
\left(\mathrm{kcal}^{-k g^{-1}}\right)\end{array}$ & $\begin{array}{c}\text { ED } \\
(\text { Gcal.m }\end{array}$ \\
\hline $\mathrm{Cc} \times \mathrm{Ct}-1$ & $545^{(9)} \mathrm{c}$ & $21,26^{(5,13)} \mathrm{b}$ & $4577^{(21)} \mathrm{b}$ & $2,49^{(0,03)} \mathrm{d}$ \\
$\mathrm{Cc} \times \mathrm{Ct}-2$ & $506^{(5)} \mathrm{d}$ & $26,84^{(7,30)} \mathrm{b}$ & $4670^{(57)} \mathrm{a}$ & $2,36^{(0,08)} \mathrm{e}$ \\
$\mathrm{Cc} \times \mathrm{Ct}-3$ & $597^{(15)} \mathrm{b}$ & $55,34^{(13,86)} \mathrm{a}$ & $4623^{(91)} \mathrm{a}$ & $2,76^{(0,18)} \mathrm{c}$ \\
$\mathrm{Ct} \times \mathrm{Cc}-4$ & $545^{(11)} \mathrm{c}$ & $31,15^{(3,96)} \mathrm{b}$ & $4659^{(41)} \mathrm{a}$ & $2,54^{(0,09)} \mathrm{d}$ \\
$\mathrm{Ct} \times \mathrm{Cc}-5$ & $641^{(14)} \mathrm{a}$ & $30,10^{(6,05)} \mathrm{b}$ & $4584^{(29)} \mathrm{b}$ & $2,94^{(0,18)} \mathrm{a}$ \\
$\mathrm{Ct} \times \mathrm{Cc}-6$ & $586^{(11)} \mathrm{b}$ & $38,35^{(6,68)} \mathrm{b}$ & $4617^{(29)} \mathrm{a}$ & $2,70^{(0,11)} \mathrm{c}$ \\
$\mathrm{Ct} \times \mathrm{Cc}-7$ & $545^{(7)} \mathrm{c}$ & $34,44^{(7,62)} \mathrm{b}$ & $4550^{(36)} \mathrm{b}$ & $2,48^{(0,14)} \mathrm{d}$ \\
\hline Mean Cc $\times \mathrm{Ct}$ & 549 & 34,48 & 4623 & 2556 \\
\hline Mean Ct $\times \mathrm{Cc}$ & 579 & 33,51 & 4603 & 2702 \\
\hline Overall mean & 566 & 33,96 & 4611 & 2640 \\
\hline CVe $(\%)$ & 7,90 & 36,77 & 1,31 & 8,40 \\
\hline
\end{tabular}

Mean values followed by the same letter do not differ from each other at $5 \%$ probability by the Scott-Knott test. Means were calculated from the five biological replications of each clone. Overall mean was calculated from all clones within each particular hybrid $(\mathrm{Cc} \mathrm{x} \mathrm{Ct}$ or $\mathrm{Ct} \times \mathrm{Cc}$ ). $\mathrm{CVe}$ : experimental coefficient of variation. $\mathrm{Cc} \times \mathrm{Ct}=$ C. citriodora $\times$ C. torelliana $\mathrm{Ct} \times \mathrm{Cc}=$ C. torelliana $\times$ C. citriodora . $\mathrm{WBD}=$ wood basic density; $\mathrm{DM}=$ dry matter; $\mathrm{HHVw}=$ high heating value of wood; and $\mathrm{ED}=$ energy density.

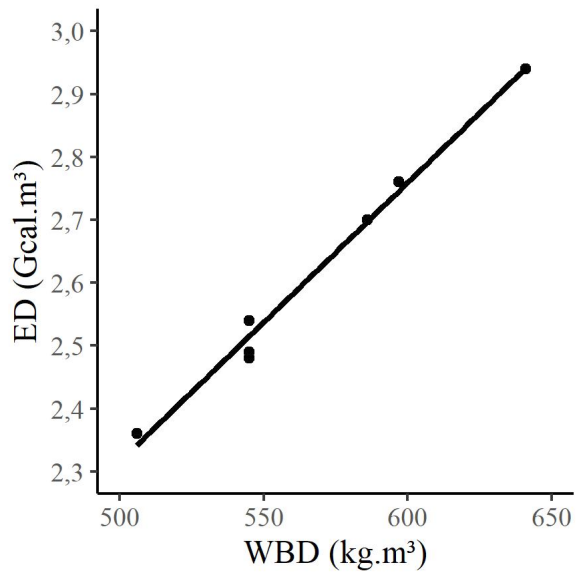

Figure 1: Positive correlation between WBD and ED.

Elemental and structural chemical composition of wood are important for charcoal production because they are the main chemical fuels (Basu 2010). Clones did not differ in elemental chemical composition nor lignin content but differed in EXT, HOLO, and ash content (Table 3). The lignin content recommended for charcoal production should be at least $28 \%$ and the clones evaluated had on average a lower content (Pereira et al. 2013). Clone Cc x Ct-1 had the highest amount of extractives and Cc x Ct-2 had the lowest. The composition of extractives may be beneficial and has previously been positively correlated to HHV of charcoal and FC (Fengel and Wegner 1989, Moya and Tenorio 2013). However, for the clones evaluated, no correlation was observed since the clones did not differ in HHVc and FC (Table 6). 
Holocellulose degradation results in increased production of non-condensable and condensable gases during charcoal production (Pereira et al. 2012). Therefore, low holocellulose content is desirable. Clone Cc $\mathrm{x}$ Ct-1 had the lowest holocellulose content while clone $\mathrm{Cc} \times \mathrm{Ct}-2$ had the highest holocellulose content $(60,16$ and $68,99 \%$ respectively; Table 3 ).

Ash content is not desirable since it is not degraded during the carbonization process. All of the clones evaluated had the desirable percentage of ash in wood (less than 1\%) (Raad and Melo 2014). Clone Cc $\times$ Ct-3 had the lowest content and clone $\mathrm{Cc} \times \mathrm{Ct}-1$ the highest $(0,29$ and $0,97 \%$ respectively; Table 3$)$.

Table 3: Mean values of elemental chemical and structural chemical composition of wood.

\begin{tabular}{|c|c|c|c|c|}
\hline \multirow{2}{*}{ Clones } & \multicolumn{4}{|c|}{ Elemental chemical composition (\%) } \\
\hline & $\mathrm{C}$ & $\mathrm{H}$ & $\mathrm{N}$ & $\mathrm{O}$ \\
\hline $\mathrm{Cc} \times \mathrm{Ct}-1$ & $45,66^{(2,98)} \mathrm{a}$ & $5,63^{(0,41)} \mathrm{a}$ & $0,76^{(0,04)} \mathrm{a}$ & $47,94^{(3,26)} \mathrm{a}$ \\
\hline $\mathrm{Cc} \times \mathrm{Ct}-2$ & $43,59^{(1,77)} \mathrm{a}$ & $5,48^{(0,28)} \mathrm{a}$ & $0,81^{(0,03)} \mathrm{a}$ & $50,12^{(2,11)} \mathrm{a}$ \\
\hline $\mathrm{Cc} \times \mathrm{Ct}-3$ & $44,33^{(2,19)} \mathrm{a}$ & $5,53^{(0,25)} \mathrm{a}$ & $0,77^{(0,02)} \mathrm{a}$ & $49,37^{(2,43)} \mathrm{a}$ \\
\hline $\mathrm{Ct} \times \mathrm{Cc}-4$ & $45,11^{(1,99)} \mathrm{a}$ & $5,57^{(0,26)} \mathrm{a}$ & $0,81^{(0,02)} \mathrm{a}$ & $48,51^{(2,19)} \mathrm{a}$ \\
\hline $\mathrm{Ct} \times \mathrm{Cc}-5$ & $45,26^{(0,56)} \mathrm{a}$ & $5,60^{(0,06)} \mathrm{a}$ & $0,78^{(0,09)} \mathrm{a}$ & $48,37^{(0,64)} \mathrm{a}$ \\
\hline $\mathrm{Ct} \times \mathrm{Cc}-6$ & $45,44^{(0,71)} \mathrm{a}$ & $5,61^{(0,11)} \mathrm{a}$ & $0,75^{(0,03)} \mathrm{a}$ & $48,20^{(0,75)} \mathrm{a}$ \\
\hline $\mathrm{Ct} \times \mathrm{Cc}-7$ & $45,05^{(0,71)} \mathrm{a}$ & $5,56^{(0,11)} \mathrm{a}$ & $0,85^{(0,12)} \mathrm{a}$ & $48,54^{(0,72)} \mathrm{a}$ \\
\hline Mean $\mathrm{Cc} \times \mathrm{Ct}$ & 44,53 & 5,55 & 0,78 & 49,14 \\
\hline Mean $\mathrm{Ct} \times \mathrm{Cc}$ & 45,22 & 5,59 & 0,80 & 48,41 \\
\hline Overall mean & 44,92 & 5,57 & 0,79 & 48,72 \\
\hline CVe $(\%)$ & 4,21 & 4,55 & 8,31 & 4,40 \\
\hline \multirow{2}{*}{ Clones } & \multicolumn{4}{|c|}{ Structural chemical composition $(\%)$} \\
\hline & EXT & LIG & HOLO & Ash \\
\hline $\mathrm{Cc} \times \mathrm{Ct}-1$ & $12,70^{(2,80)} \mathrm{a}$ & $26,16^{(1,41)} \mathrm{a}$ & $60,16^{(1,98)} \mathrm{c}$ & $0,97^{(0,15)} \mathrm{a}$ \\
\hline $\mathrm{Cc} \times \mathrm{Ct}-2$ & $4,46^{(0,45)} \mathrm{d}$ & $26,00^{(1,04)} \mathrm{a}$ & $68,99^{(1,24)} \mathrm{a}$ & $0,55^{(0,17)} \mathrm{c}$ \\
\hline $\mathrm{Cc} \times \mathrm{Ct}-3$ & $6,72^{(0,90)} \mathrm{c}$ & $25,90^{(1,78)} \mathrm{a}$ & $67,09^{(2,34)} \mathrm{b}$ & $0,29^{(0,07)} \mathrm{d}$ \\
\hline $\mathrm{Ct} \times \mathrm{Cc}-4$ & $10,35^{(0,56)} \mathrm{b}$ & $26,24^{(3,02)} \mathrm{a}$ & $62,57^{(2,81)} \mathrm{b}$ & $0,84^{(0,14)} \mathrm{b}$ \\
\hline $\mathrm{Ct} \times \mathrm{Cc}-5$ & $9,46^{(1,36)} \mathrm{b}$ & $25,71^{(1,19)} \mathrm{a}$ & $64,05^{(2,44)} \mathrm{b}$ & $0,78^{(0,08)} \mathrm{b}$ \\
\hline $\mathrm{Ct} \times \mathrm{Cc}-6$ & $8,69^{(0,88)} \mathrm{b}$ & $26,94^{(1,25)} \mathrm{a}$ & $63,60^{(1,28)} \mathrm{b}$ & $0,77^{(0,10)} \mathrm{b}$ \\
\hline $\mathrm{Ct} \times \mathrm{Cc}-7$ & $9,15^{(0,28)} \mathrm{b}$ & $27,31^{(1,19)} \mathrm{a}$ & $63,02^{(1,19)} \mathrm{b}$ & $0,52^{(0,11)} \mathrm{c}$ \\
\hline Mean $\mathrm{Cc} \times \mathrm{Ct}$ & 7,96 & 26,02 & 65,41 & 0,60 \\
\hline Mean $\mathrm{Ct} \times \mathrm{Cc}$ & 9,41 & 26,55 & 63,31 & 0,73 \\
\hline Overall mean & 8,79 & 26,32 & 64,21 & 0,67 \\
\hline CVe $(\%)$ & 14,79 & 6,39 & 3,11 & 18,08 \\
\hline
\end{tabular}

Mean values followed by the same letter do not differ by the Scott-Knott test, at $5 \%$ probability. Overall mean: average from all of the clones within this particular cross. CVe: experimental coefficient of variation. $\mathrm{Cc} \times \mathrm{Ct}=$ C. citriodora $\times$ C. torelliana $\mathrm{Ct} \times \mathrm{Cc}=$ C. torelliana $\times$ C. citriodora; numbers refer to the clone number; $\mathrm{C}=$ carbon content; $\mathrm{H}=$ hydrogen content; $\mathrm{N}=$ nitrogen content; $\mathrm{O}=$ oxygen; EXT = total extractive content; $\mathrm{LIG}=$ total lignin content; $\mathrm{HOLO}=$ Total holocellulose content; Ash = Ash content

The oxidation elements $\mathrm{C}, \mathrm{H}$, and $\mathrm{O}$ influence the conversion of in natura biomass to biofuel and contribute to burning performance (Ronsse et al. 2015). These elements contribute most to the calorific value of fuel (Huang et al. 2009). Higher $\mathrm{H} / \mathrm{C}$ ratios result in higher $\mathrm{HHVw}$, and higher $\mathrm{O}$ and ash content results in lower HHV (Ahmad and Subawi, 2013). Clone $\mathrm{Cc} \times \mathrm{Ct}-2$ had the highest $\mathrm{H} / \mathrm{C}$ content and lowest $\mathrm{O} / \mathrm{C}$ content (Figure 2). Clone $\mathrm{Cc} \times \mathrm{Ct}-2$ had the highest $\mathrm{H} / \mathrm{C}$ content and lowest $\mathrm{O} / \mathrm{C}$ content combined (Figure 2) with a low ash content (Table 3 ). Clone $\mathrm{Cc} \times \mathrm{Ct}-3$ also had high $\mathrm{H} / \mathrm{C}$ content and the lowest ash content. However, no correlation was found between $\mathrm{H} / \mathrm{C}$ content and $\mathrm{HHVw}$, and $\mathrm{O} / \mathrm{C}$ content and $\mathrm{HHVw}$. These characteristics are 
important for selection of material with great potential for bioenergy.

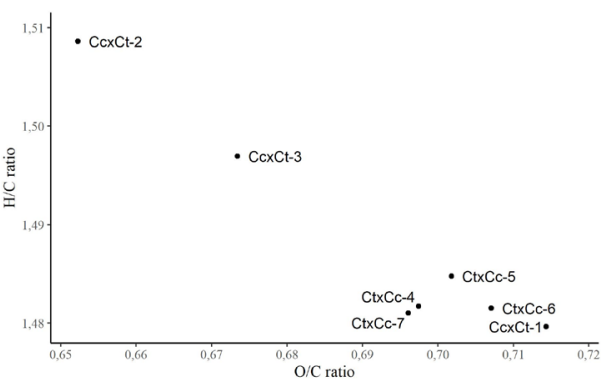

Figure 2: Van Krevelen diagram of seven selected Corymbia hybrids wood.

Thermogravimetric analysis indicates thermal stability by monitoring the weight change that occurs as a sample is heated. Through thermogravimetry/derivative thermogravimetry (TG/DTG) the present study shows that all clones had similar mass loss in the temperature from $40^{\circ} \mathrm{C}$ to $400{ }^{\circ} \mathrm{C}$ (Figure 3) and TG/DTG displays four steps. The first step occurred between $40-100{ }^{\circ} \mathrm{C}$ and clones lost a mean of $5,81 \%$ of mass; the second step occurred between $100{ }^{\circ} \mathrm{C}$ to $250{ }^{\circ} \mathrm{C}$ and clones lost a mean mass of $4,52 \%$; the third step represents the biggest average mass loss of $57,67 \%$ in a temperature range of $250-380{ }^{\circ} \mathrm{C}$; the forth step occurred between $380-600{ }^{\circ} \mathrm{C}$ and the average mass loss was $11,75 \%$ (Table 4 ).
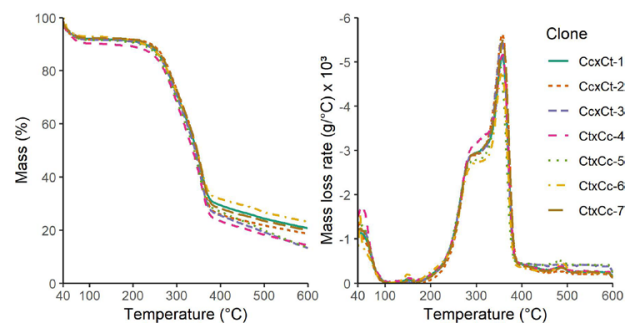

Figure 3: Thermogravimetry/derivative thermogravimetry (TG/DTG) curves from Corymbia hybrid clones wood samples under an inert atmosphere (pyrolysis conditions).

The greatest mass losses occurred in the range of 250 to $380{ }^{\circ} \mathrm{C}$ (Table 4 ) followed by the range of 380 to $600{ }^{\circ} \mathrm{C}$. Thermal decomposition of holocellulose occurs between 220 and $400{ }^{\circ} \mathrm{C}$ (Yang et al. 2007). The TG/ DTG curve shows that the HOLO degradation may occur mainly during the third step and the mass loss was approximately $60 \%$, which was proportional to the HOLO content in the wood (64\% of holocellulose) (Figure 3 , Table 3). Clone $\mathrm{Ct} \times \mathrm{Cc}-6$ had the highest percentage of residual mass, which corroborates with its higher content of EXT, ash, and a lower percentage of HOLO. Clones with higher residual masses are expected to have higher charcoal yields due to their higher thermal stability. 
Table 4: Mass loss of Corymbia hybrid clones wood in function of temperature and percentage of residual mass obtained from the TG/DTG measurements.

\begin{tabular}{|c|c|c|c|c|c|}
\hline \multirow{2}{*}{ Clones } & \multicolumn{4}{|c|}{ Temperature ranges $\left({ }^{\circ} \mathbf{C}\right)$} & \multirow{2}{*}{ Residual mass (\%) } \\
\cline { 2 - 5 } & $\mathbf{4 0 - 1 0 0}$ & $\mathbf{1 0 0 - 2 5 0}$ & $\mathbf{2 5 0 - 3 8 0}$ & $\mathbf{3 8 0 - 6 0 0}$ & \\
\hline Cc x Ct-1 & 4,98 & 4,54 & 55,88 & 10,73 & 20,71 \\
\hline Cc x Ct-2 & 6,57 & 2,94 & 60,22 & 9,79 & 20,47 \\
\hline Cc x Ct-3 & 5,14 & 4,44 & 59,47 & 14,25 & 16,69 \\
\hline Ct x Cc-4 & 6,16 & 5,14 & 59,47 & 11,27 & 17,95 \\
\hline Ct x Cc-5 & 5,20 & 5,20 & 57,43 & 15,29 & 16,88 \\
\hline Ct x Cc-6 & 6,59 & 5,43 & 53,45 & 10,32 & 24,20 \\
\hline Ct x Cc-7 & 6,00 & 3,94 & 57,75 & 10,57 & 21,73 \\
\hline
\end{tabular}

\section{Charcoal evaluations}

Gravimetric carbonization yields, gravimetric pyroligneous liquid yield, and gravimetric non-condensable gas yield were evaluated; however, no differences were observed among clones (Table 5). Apparent relative density (ARD) means varied among charcoal from different clones (Table 5). Clone $\mathrm{Ct} \times \mathrm{Cc}-5$ had the highest mean and clone $\mathrm{Cc} \times \mathrm{Ct}-2$ the lowest.BD and $\mathrm{ARD}$ were positively correlated, with a correlation coefficient of 0,96 ( $p$-value $<0,05 ; R^{2}=0,92 ; y=0,9503 x-115,09$; Figure 4). Although WBD cannot be used to predict charcoal yield directly, it can be a good parameter to consider. Positive correlation between WBD and ARD was previously reported in Eucalyptus spp. (Pereira et al. 2012, Andrade et al. 2018). ARD of charcoal in the range of 250 to $280 \mathrm{~kg} \cdot \mathrm{m}^{-3}$ provides better reduction performance in the blast furnace, savings in charcoal consumption, more FC which is transported and discharged at the steel mill. So, there is greater financial return when compared with the performance of lower density charcoal (Isbaex 2018).

Table 5: Mean values of apparent density of charcoal and gravimetric yields of carbonization.

\begin{tabular}{|l|c|c|c|c|}
\hline \multicolumn{1}{|c|}{ Clones } & ARD (kg.m- & GCY (\%) & GYP (\%) & GNCY (\%) \\
\hline $\mathrm{Cc} \times \mathrm{Ct}-1$ & $426^{(19)} \mathrm{b}$ & $35,85^{(0,70)} \mathrm{a}$ & $42,29^{(5,42)} \mathrm{a}$ & $21,86^{(5,00)} \mathrm{a}$ \\
\hline $\mathrm{Cc} \times \mathrm{Ct}-2$ & $358^{(15)} \mathrm{d}$ & $33,87^{(0,67)} \mathrm{a}$ & $46,44^{(2,67)} \mathrm{a}$ & $19,68^{(2,01)} \mathrm{a}$ \\
\hline $\mathrm{Cc} \times \mathrm{Ct}-3$ & $443^{(7)} \mathrm{b}$ & $36,26^{(2,76)} \mathrm{a}$ & $43,66^{(3,97)} \mathrm{a}$ & $20,07^{(3,72)} \mathrm{a}$ \\
\hline $\mathrm{Ct} \times \mathrm{Cc}-4$ & $406^{(19)} \mathrm{c}$ & $34,99^{(0,40)} \mathrm{a}$ & $43,14^{(2,50)} \mathrm{a}$ & $21,88^{(2,13)} \mathrm{a}$ \\
\hline $\mathrm{Ct} \times \mathrm{Cc}-5$ & $501^{(18)} \mathrm{a}$ & $34,63^{(0,60)} \mathrm{a}$ & $44,68^{(3,45)} \mathrm{a}$ & $20,70^{(3,28)} \mathrm{a}$ \\
\hline $\mathrm{Ct} \times \mathrm{Cc}-6$ & $431^{(16)} \mathrm{b}$ & $35,63^{(2,43)} \mathrm{a}$ & $42,02^{(4,46)} \mathrm{a}$ & $22,35^{(3,14)} \mathrm{a}$ \\
\hline $\mathrm{Ct} \times \mathrm{Cc}-7$ & $397^{(17)} \mathrm{c}$ & $34,31^{(0,51)} \mathrm{a}$ & $46,12^{(2,90)} \mathrm{a}$ & $19,57^{(2,49)} \mathrm{a}$ \\
\hline Mean Cc $\times \mathrm{Ct}$ & 409 & 35,33 & 44,13 & 20,54 \\
\hline Mean Ct $\times \mathrm{Cc}$ & 434 & 34,89 & 43,99 & 21,13 \\
\hline Overall mean & 423 & 35,08 & 44,05 & 20,87 \\
\hline $\mathrm{CVe}(\%)$ & 3,82 & 4,21 & 8,52 & 15,60 \\
\hline
\end{tabular}

Mean values followed by the same letter do not differ from each other at $5 \%$ probability by the Scott-Knott test. CVe: Experimental Coefficient of Variation. $\mathrm{Cc} \times \mathrm{Ct}=C$. citriodora $\times$ C. torelliana $; \mathrm{Ct} \times \mathrm{Cc}=$ C. torelliana $\times$ C. citriodora $. \mathrm{ARD}=\mathrm{apparent}$ relative density; GCY = gravimetric carbonization yields; GYP = gravimetric yield of pyroligneous liquid and GNCY $=$ gravimetric yield of non-condensable gases.

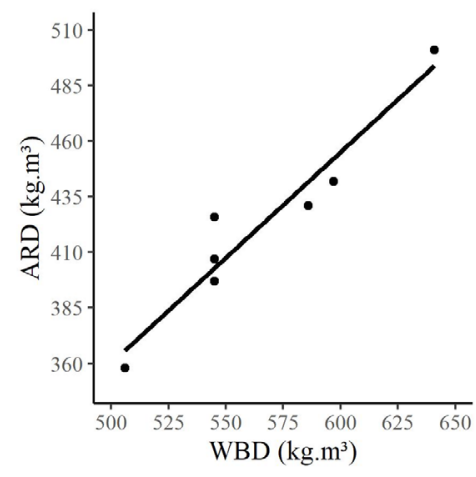

Figure 4: Positive correlation between WBD and ARD.

All clones had equal HHVc, VM, FC, and EE but differed in ash content (Table 6). No correlation was 
found between WBD and HHVc or EE which means that WBD is not a good parameter for clone selection in this study for charcoal quality. The HHVc is highly dependent on FC and VM (Trugilho and Silva 2001, Vale et al. 2001). Since these contents were equal among clones the HHVc also did not differ among clones. The ash content was high for $\mathrm{Cc} \times \mathrm{Ct}-1, \mathrm{Ct} \times \mathrm{Cc}-4$, and $\mathrm{Ct} \times \mathrm{Cc}-6$, and low for $\mathrm{Cc} \times \mathrm{Ct}-2, \mathrm{Cc} \times \mathrm{Ct}-3, \mathrm{Ct} \times \mathrm{Cc}-5$, and $\mathrm{Ct}$ $\times$ Cc-7 (Table 6). Ideally the ash content should be less than 1\% (Raad and Melo 2014) which was observed only for clone $\mathrm{Cc} \times \mathrm{Ct}-3$.

Table 6: Mean values of HHVc, proximate composition, and EE of charcoal.

\begin{tabular}{|c|c|c|c|c|c|}
\hline \multirow{2}{*}{ Clones } & \multirow{2}{*}{ HHVc $\left(\mathbf{k c a l ~ k g}^{-1}\right)$} & \multicolumn{3}{|c|}{ Proximate analysis (\%) } & \multirow{2}{*}{ EE (\%) } \\
\cline { 3 - 5 } & & VM & FC & ASH & \\
\hline $\mathrm{Cc} \times \mathrm{Ct}-1$ & $7358^{(93)} \mathrm{a}$ & $23,29^{(0,65)} \mathrm{a}$ & $75,39^{(0,71)} \mathrm{a}$ & $1,32^{(0,10)} \mathrm{a}$ & $57,61^{(0,96)} \mathrm{a}$ \\
\hline $\mathrm{Cc} \times \mathrm{Ct}-2$ & $7445^{(113)} \mathrm{a}$ & $22,54^{(0,83)} \mathrm{a}$ & $76,31^{(0,97)} \mathrm{a}$ & $1,15^{(0,20)} \mathrm{b}$ & $54,00^{(1,23)} \mathrm{a}$ \\
\hline $\mathrm{Cc} \times \mathrm{Ct}-3$ & $7354^{(260)} \mathrm{a}$ & $26,57^{(6,23)} \mathrm{a}$ & $72,54^{(6,11)} \mathrm{a}$ & $0,89^{(0,13)} \mathrm{b}$ & $57,62^{(3,71)} \mathrm{a}$ \\
\hline $\mathrm{Ct} \times \mathrm{Cc}-4$ & $7342^{(76)} \mathrm{a}$ & $23,20^{(0,66)} \mathrm{a}$ & $75,39^{(0,84)} \mathrm{a}$ & $1,41^{(0,32)} \mathrm{a}$ & $55,13^{(0,51)} \mathrm{a}$ \\
\hline $\mathrm{Ct} \times \mathrm{Cc}-5$ & $7388^{(28)} \mathrm{a}$ & $23,65^{(0,76)} \mathrm{a}$ & $75,33^{(0,68)} \mathrm{a}$ & $1,02^{(0,09)} \mathrm{b}$ & $55,80^{(0,91)} \mathrm{a}$ \\
\hline $\mathrm{Ct} \times \mathrm{Cc}-6$ & $7308^{(107)} \mathrm{a}$ & $22,78^{(0,15)} \mathrm{a}$ & $75,76^{(0,41)} \mathrm{a}$ & $1,46^{(0,33)} \mathrm{a}$ & $56,40^{(4,05)} \mathrm{a}$ \\
\hline $\mathrm{Ct} \times \mathrm{Cc}-7$ & $7432^{(84)} \mathrm{a}$ & $22,31^{(0,43)} \mathrm{a}$ & $76,59^{(0,51)} \mathrm{a}$ & $1,10^{(0,13)} \mathrm{b}$ & $56,04^{(0,81)} \mathrm{a}$ \\
\hline Mean Cc $\times \mathrm{Ct}$ & 7386 & 24,13 & 74,75 & 1,12 & 56,41 \\
\hline Mean Ct $\times \mathrm{Cc}$ & 7368 & 22,99 & 75,77 & 1,15 & 55,84 \\
\hline Overall mean & 7375 & 23,48 & 75,33 & 1,19 & 56,09 \\
\hline CVe $(\%)$ & 1,73 & 10,32 & 3,19 & 17,56 & 3,95 \\
\hline
\end{tabular}

Mean values followed by the same letter do not differ by the Scott-Knott test, at $5 \%$ probability. CVe: experimental coefficient of variation. $\mathrm{Cc} \times \mathrm{Ct}=$ C. citriodora $\times$ C. torelliana $\mathrm{Ct} \times \mathrm{Cc}=$ C. torelliana $\times$ C. citriodora HHVc $=$ High Heating Value of Charcoal; $\mathrm{VM}=$ Volatile Materials; FC $=$ Fixed Carbon; $\mathrm{EE}=$ Energy Efficiency.

\section{CONCLUSIONS}

All clones tested have potential use for charcoal production due to good quality and equal results for the most important parameters evaluated for charcoal. Selecting clones $\mathrm{Cc} \times \mathrm{Ct}-2, \mathrm{Cc} \times \mathrm{Ct}-3, \mathrm{Ct} \times \mathrm{Cc}-5$, and $\mathrm{Ct} \times$ Cc-7 may be desirable due to their low ash content. Positive correlation was found between wood parameters WBD and ED, and wood versus charcoal parameters, WBD and ARD. However, there were no correlations between wood and charcoal quality parameters that could be used to select a clone that could reflect the charcoal quality since the quality of charcoal from different clones was very similar. Using hybrid clones of Corymbia for charcoal production may be a good alternative due to their fast growth and similar qualities of wood and charcoal to other species that have already been used.

\section{ACKNOWLEDGEMENTS}

The preparation of this study was supported by UFLA (Universidade Federal de Lavras, Lavras, Brazil), CNPq (Conselho Nacional de Desenvolvimento Científico e Tecnológico), CAPES (Coordenação de Aperfeiçoamento de Pessoal de Nível Superior) and FAPEMIG (Fundação de Amparo à Pesquisa do Estado de Minas Gerais). The authors would like to thank for their scientific, technical and financial support. We thank Dr. Camila M. L. Alves and Ilse Renner for the feedback, English translation and proofreading and edits.

\section{REFERENCES}

ABNT. NBR. 2003. Wood - Determination of basic density. ABNT. NBR 11941. 2003. Rio de Janeiro.

ABNT. NBR. 2017. Paper, board, pulps and wood - Determination of residue (ash) on ignition at $525{ }^{\circ} \mathrm{C}$. ABNT. NBR 13999. 2017. Rio de Janeiro.

ASTM International. ASTM. 2004. Standard test method for gross calorific value of refuse-derived fuel by the bomb calorimeter. ASTM. E 711-87. 2004. ASTM International, West Conshohocken, PA.

ASTM International. ASTM. 2007. Standard Test Method for Chemical Analysis of Wood Charcoal. ASTM. D1762-84. 2007. ASTM International, Conshohocken, PA. 
Ahmad, M.; Subawi, H. 2013. New Van Krevelen diagram and its correlation with the heating value of biomass. Journal of Agriculture and Environmental Management 2(10): 295-301.

Andrade, F.W.C.; Tomazello Filho, M.; Moutinho, V.H.P. 2018. Influence of wood physical properties on charcoal from Eucalyptus spp. Floresta e Ambiente 25(3): 1-8.

Assis, M.R.; Trugilho, P.F.; Rosado, S.C.D.S.; Protásio, T.P.; Goulart, S.L. 2015. Modelagem da biomassa e do estoque de carbono em plantas jovens de Eucalyptus. Scientia Forestalis 43(105): 401-408.

Basu, P. 2010. Biomass gasification and pyrolysis: Practical Design. Elsevier: Oxford, 365 p. ISBN 9780-12-374988-8.

Brito, J.O.; Barrichelo, L.E.G. 1980. Correlações entre características físicas e químicas da madeira e a produção de carvão: 2. densidade da madeira x densidade do carvão. IPEF 20:121-126.

Bruzual, C.F. 2015. Assessment of $\mathrm{CO}_{2}$ mitigation potential, biomass use and plantation areas to sustain charcoal-ironmaking. Tecnologia em Metalurgia, Materiais e Mineração 12(4): 325-334.

Ashton, S.; \& Cassidy, P. 2007. Energy Basics. In: Hubbard, W.; L. Biles; C. Mayfield; S. Ashton (Eds.). 2007. Sustainable Forestry for Bioenergy and Bio-based Products: Trainers Curriculum Notebook. Athens, GA: Southern Forest Research Partnership, Inc. 316 p. <http://www.forestbioenergy.net/training-materials/ training-curriculum-notebook/BiomassTrainNotebook.pdf $>$ (Accessed: 03 July 2019).

Chrzazvez, J.; Théry-Parisot, I.; Fiorucci, G.; Terral, J.F.; Thibaut, B. 2014. Impact of postdepositional processes on charcoal fragmentation and archaeobotanical implications: experimental approach combining charcoal analysis and biomechanics. Journal of Archaeological Science 44: 30-42.

Downes, G.M.; Hudson, I.L.; Raymond, C.A.; Dean, G.H.; Michell, A.J.; Schimleck, R.; Evans, R.; Muneri, A. 1997. Sampling plantation eucalypts for wood and fiber properties. Collingwood: Melbourne: CSRIO, 126 p. ISBN 0-643-06284-X.

Elaieb, M.T.; Khouaja, A.; Khouja, M.L.; Valette, J.; Volle, G.; Candelier, K. 2018. Comparative study of local tunisian woods properties and the respective qualities of their charcoals produced by a new industrial eco-friendly carbonization process. Waste and Biomass Valorization 9(7): 1199-1211.

FAO. 2019. FAOSTAT: Forestry Data. (online) <http://faostat3.fao.org/browse/F/FO/E $>$. (Accessed: 03 July 2019).

Fengel, D.; Wegener, G. 1989. Wood: Chemistry, Ultrastructure, Reactions. New York: de Gruyter, 613 p. ISBN: 3-11-012059-3.

Fialho, L.D.F.; Carneiro, A.D.C.O.; Carvalho, A.M.M.L.; Figueiró, C.G.; Silva, C.M.S.D.; Magalhães, M.A.; Peres, L.C. 2019. Bio-coal production with agroforestry biomasses in Brazil. MaderasCienc Tecnol 21(3): 357-366.

Goldschmid, O. 1971. Ultraviolet spectra. In: SARKANEN, K.V.; LUDWIG, C.H. (Eds.) Lignins: Occurrence, formation, structure and reactions. New York: Wiley-Interscience, 1971. 916 p. ISBN 0-47175422-6.

Gomide, J.L.; Demuner, B.J. 1986. Determinação do teor de lignina em material lenhoso: método Klarson modificado. O Papel 47(8): 36-38.

Gonçalves, B.; Dustin, T.; Oladiran, F.; Bijay, T.; Tom, G. 2015. Influence of bark on the physical and thermal decomposition properties of short-rotation Eucalyptus. BioEnergy Research 8(3): 1414-1423.

Guo, X.; Wang, S.; Wang, K.; Liu, Q.; Luo, Z. 2010. Influence of extractives on mechanism of biomass pyrolysis. Journal of Fuel Chemistry and Technology 38(1): 42-46. 
Haykiri-Acma, H.; Yaman, S.; Kucukbayrak, S. 2010. Comparison of the thermal reactivities of isolated lignin and holocellulose during pyrolysis. Fuel Processing Technology 91(7): 759-764.

Healey, A.L.; Lupoi, J.S.; Lee, D.J.; Sykes, R.W.; Guenther, J.M.; Tran, K.; Decker, S.R.; Singh, S.; Simmons, B.A.; Henry, R.J. 2016. Effect of aging on lignin content, composition and enzymatic saccharification in Corymbia hybrids and parental taxa between years 9 and 12. Biomass and Bioenergy 93: $50-59$.

Huang, C.; Han, L.; Yang, Z.; Liu, X. 2009. Ultimate analysis and heating value prediction of straw by near infrared spectroscopy. Waste Management 29(6): 1793-1797.

Isbaex, C. 2018. Influence of the charcoal density on the production pig iron. Ph.D. Thesis, Universidade Federal de Viçosa, Viçosa, Brazil. 124p. < http://www.locus.ufv.br/handle/123456789/23568> (Accessed: 03 July 2019).

Lee, D.J. 2007. Achievements in forest tree genetic improvement in Australia and New Zealand 2: Development of Corymbia species and hybrids for plantations in eastern Australia. Australian Forestry 70(1): 11-16.

Lee, D.J.; Huth, J.R.; Brawner, J.; Dickinson, G. 2009. Comparative performance of Corymbia hybrids and parental species in subtropical Queensland and implications for breeding and deployment. Silvae Genetica 58(5-6): 202-212.

Lin, S.Y.; Hirato, M.; Horio, M. 1994. The characteristics of coal char gasification at around ash melting temperature. Energy \& Fuels 8(3): 598-606.

Moutinho,V.H.P.;TomazelloFilho,M.;Brito,J.O.;Ballarin,A.W.;Andrade,F.W.C.2016.Influenceofthe woodphysical properties on the charcoal physical andmechanical properties. Scientia Forestalis 44(111):557-561.

Moya, R.; Tenorio, C. 2013. Fuel characteristics and its relation with extractives and chemical properties of ten fast-growth species in Costa Rica. Biomass and Bioenergy 56: 14-21.

Oliveira, A.C.; Carneiro, A.C.O.; Vital, B.R.; Almeida, W.; Pereira, B.L.C.; Cardoso, M. T. 2010. Parâmetros de qualidade da madeira e do carvão vegetal de Eucalyptus pellita F. Muell. Scientia Forestalis 38(87): 431-439.

Peel, M.C.; Finlayson, B.L.; Mcmahon, T.A. 2007. Updated world map of the Köppen-Geiger climate classification. Hydrology and Earth System Sciences 4(2): 1633-1644.

Pereira, B.L.C.; Carneiro, A.C.O.; Carvalho, A.M.M.L.; Colodette, J.L.; Oliveira, A.C.; Fontes, M.P.F. 2013. Influence of chemical composition of eucalyptus wood on gravimetric yield and charcoal properties. BioResources 8(3): 439-473.

Pereira, B.L.C.; Oliveira, A.C.; Carvalho, A.M.M.L.; Carneiro, A.D.C.O.; Santos, L.C.; Vital, B.R. 2012. Quality of wood and charcoal from Eucalyptus clones for ironmaster use. International Journal of Forestry Research 2012: 1-8.

Protásio, T.P.; Goulart, S.L.; Neves, T.A.; Trugilho, P.F.; Ramalho, F.M.G.; Queiroz, L.M.R.S.B. 2014. Qualidade da madeira e do carvão vegetal oriundos de floresta plantada em Minas Gerais. Brazilian Journal of Forestry Research 34(78): 111-123.

Protásio, T.P.; Couto, A.M.; Trugilho, P.F.; Guimarães Junior, J.B; Lima Junior, P.H.; Silva, M.M.O. 2015. Avaliação tecnológica do carvão vegetal da madeira de clones jovens de Eucalyptus grandis e Eucalyptus urophylla. Scientia Forestalis 43(108): 801-816.

Protásio, T.P.; Trugilho, P.F.; Araújo, A.C.C.; Bastos, T.A.; Rosado, S.C.S.; Pinto, J.F.N. 2017. Classification of Eucalyptus clones by the ratio syringyl/guaiacyl and growth characteristics for energy use. Scientia Forestalis 45(114): 327-341. 
Protásio, T.P.; Scatolino, M.V.; Araújo, A.C.C.; Oliveira, A.F.C.F.; Figueiredo, I.C.R.; Assis, M.R.; Trugilho, P.F. 2019. Assessing Proximate Composition, Extractive Concentration, and Lignin Quality to Determine Appropriate Parameters for Selection of Superior Eucalyptus Firewood. BioEnergy Research 12(3): 626-641.

Raad, T.J.; Melo, V.F. 2014. Mapeamento de ações institucionais para sustentabilidade da produção de ferro-gusa a partir de carvão vegetal. Technical note. Brasília: Centro de Gestão e Estudos Estratégicos, 26 p.

Reis, C.A.F.; Assis, T.F.; Santos, A.M.; Paludzysyn, E.F. 2014. Corymbia torelliana: estado da arte de pesquisas no Brasil. Colombo: Embrapa Florestas 261:50<https:/ainfo.cnptia.embrapa.br/digital/bitstream/ item/113641/1/Doc.-261-Reis.pdf> (Accessed: 03 July 2019).

Ronsse, F.; Nachenius, R.W.; Prins, W. 2015. Carbonization of Biomass, Recent Advances in ThermoChemical Conversion of Biomass. Elsevier: Amsterdam, 504p. ISBN 978-0-444-63289-0.

Rousset, P.; Figueiredo, C.; De Souza, M.; Quirino, W. 2011. Pressure effect on the quality of eucalyptus wood charcoal for the steel industry: A statistical analysis approach. Fuel Processing Technology 92(10): 18901897.

Santos, R.C.; Carneiro, A.D.C.O.; Castro, A.F.M.; Castro, R.V.O.; Souza, M.M.; Cardoso, M.T. 2011. Correlações entre os parâmetros de qualidade da madeira e do carvão vegetal de clones de eucalipto. Scientia Forestalis 39(90): 221-230.

Silva, F.T.M.; Ataíde, C.H. 2019. Valorization of Eucalyptus urograndis wood via carbonization: Product yields and characterization. Energy 172: 509-516.

Soares, V.C.; Bianchi, M.L.; Trugilho, P.F.; Pereira, A.J.; Höfler, J. 2014. Correlações entre as propriedades da madeira e do carvão vegetal de híbridos de eucalipto. Revista Árvore 38(3): 543-549.

TAPPI Standard. 2001. Solvent extractives of wood and pulp. TAPPI.T 204 om-88. 2001. TAPPI Standard Method: Atlanta, USA.

Trugilho, P.F.; Silva, D.A. 2001. Influência da temperatura final de carbonização nas características físicas e químicas do carvão vegetal de jatobá (Himenea courbaril L.). Scientia Agraria 2(1-2): 45-53.

Trugilho, P.F. 2009. Densidade básica e estimativa de massa seca e de lignina na madeira em espécies de Eucalyptus. Ciência e Agrotecnologia 33(5): 1228-1239.

Vale, A.T.; Costa, A.F.; Gonçalez, J.C.; Nogueira, M. 2001. Relações entre a densidade básica da madeira, o rendimento e a qualidade do carvão vegetal de espécies do cerrado. Revista Árvore 25(89): 89-95.

Van Krevelen, D.W. 1993. Coal: typology, physics, chemistry, constitution. Elsevier Science: Amsterdam 1000 p. ISBN 0-444-89586-8.

Wang, S.; Dai, G.; Yang, H.; Luo, Z. 2017. Lignocellulosic biomass pyrolysis mechanism: a state of the art review. Progress in Energy and Combustion Science 62: 33-86.

Yang, H.; Yan, R.; Chen, H.; Lee, D.H.; Zheng, C. 2007. Characteristics of hemicellulos, cellulose and lignin pyrolysis. Fuel 86(12-13): 1781-1788.

Zanuncio, A.J.V.; Carvalho, A.G.; Trugilho, P.F.; Monteiro, T.C. 2014a. Extractives and energetic properties of wood and charcoal. Revista Árvore 38(2): 369-374.

Zanuncio, A.J.V.; Lima, J.T.; Monteiro, T.C.; Trugilho, P.F.; Lima, F.S. 2014b. Outdoor drying of wood for charcoal production. Floresta e Ambiente 21(3): 401-408.

Zanuncio, A.J.V.; Carvalho, A.G.; Silva, L.F.; Lima, J.T.; Trugilho, P.F.; Silva, J.R.M. 2015. Predicting moisture content from basic density and diameter during air drying of Eucalyptus and Corymbia logs. Maderas-Cienc Tecnol 17(2): 335-344. 